\title{
Effects of a Plant-Cushioning Material Containing Tangerine Oil on Bruising and Mould Growth of Banana (Kluai Hom Thong) and its Potential Reuse
}

\author{
Ravinun Saengwong-ngam, ${ }^{\mathrm{a}, \mathrm{c}}$ Narumol Matan, ${ }^{\mathrm{a}, \mathrm{c}, *}$ and Nirundorn Matan ${ }^{\mathrm{b}}$ \\ The objectives of this study were to investigate the effects of a plant- \\ cushioning material containing tangerine oil in conserving the quality of a \\ Kluai Hom Thong banana during transportation and storage. In addition, \\ the reuse of the plant-cushioning material with and without tangerine oil \\ for two, three, or four transportation and storage cycles was investigated. \\ The results demonstrated that the plant-cushioning material with tangerine \\ oil protected the Kluai Hom Thong banana from mould growth by $100 \%$ \\ and it reduced the bruised areas on the banana peel by $80 \%$. The \\ tangerine oil vapour released from the plant-cushioning material might \\ also affect the ripening of the banana, since the colour changed from \\ green to yellow more quickly in the fruit that had been treated with \\ tangerine oil compared to the control fruit. In addition, this intelligent \\ cushioning material containing tangerine oil has great potential in reducing \\ bruised areas, inhibiting mould and extending the quality of the banana \\ during transportation and storage ( 14 days) for at least one time compared \\ to the control (5 to 7 days). The reuse of the plant-cushioning material, at \\ least up to four times with and without tangerine oil for the protection of \\ the banana, showed great potential.
}

DOI: 10.15376/biores.17.1.37-51

Keywords: Banana fruit; Transportation; Tangerine oil; Cushioning material; Reuse

Contact information: a: Food Industry, School of Agricultural Technology and Food Industry, Walailak University, Nakhon Si Thammarat 80160 Thailand; b: Center of Excellence in Wood Science and Engineering, School of Engineering and Technology, Walailak University, Nakhon Si Thammarat 80160 Thailand; c: Research Center of Excellence in Innovation of Essential Oil, Walailak University, Nakhon Si Thammarat, 80160 Thailand; *Corresponding author: nnarumol@wu.ac.th; nnarumol@yahoo.com

\section{INTRODUCTION}

The Kluai Hom Thong banana belongs to the AAA group 'Gros Michel' and is a major fruit for the economy of Thailand. After harvesting and also during transportation to market, the quality of the banana may deteriorate due to its short shelf-life (Maqbool et al. 2010). Poor transportation standards, e.g., improper packaging and a lack of sanitation, has been found to have a substantial effect on the banana because it is highly susceptible to physical injury during transportation (Kuyu and Tola 2018). Poor transportation methods can lead to intensive bruising, softening of the tissue, dark skin, and reduced firmness caused by rapid microbial deterioration; this results in a low price on the export market (Raybaudi-Massilia et al. 2009). Physical damage due to the bruising of the banana significantly correlates to the quality of the fruit, e.g., high weight loss and rapid mould spoilage (Jagannath et al. 2005). Fungal diseases on the surface of the banana before consumption are a major contributor to its short shelf-life; these are caused by a lack of 
proper handling in the postharvest chain (Raybaudi-Massilia et al. 2009; Kuyu and Tola 2018). Fungal infection in the banana, such as Fusarium incarnatum, Colletotrichum musae, Lasiodiplodia theobromae, Nigrospora sp., and Alternaria sp., causes mycelium growth on the crown surface, resulting in the softening and blackening of the tissue (Kamel et al. 2016). Some mould species found in diseased bananas are known to result in some human diseases (Triest and Hendrickx 2016).

Various packaging features that reduce physical damage and, therefore, protect and preserve bananas during transportation, are of current interest. Cushioning material (CM), which can easily be added to shipping packaging, is one of the more effective methods of protection. The $\mathrm{CM}$ can be made from a plant product, e.g., bamboo fibre or a water plant, which replaces synthetic materials, e.g., foam or plastic, in an effective way to protect the banana. These plant fibres have beneficial properties, e.g., they absorb energy, are lightweight, and have excellent physical properties (Phothisuwan et al. 2020). In addition, based on their structural characteristics, e.g., intelligent, functionally graded material (Tan et al. 2011), they have a low density and low cost due to their high growth rate and high degree of strength (Hao et al. 2018). Furthermore, the CM packaging design and plant material selection can be reused, which is a major sustainable feature. In addition, the modification of the $\mathrm{CM}$ can reduce bruising and increase the inhibition of microbial activity.

An antimicrobial agent, e.g., essential oil, is a good alternative due to its biological properties and the fact that it is generally recognized as safe by the US Food and Drug Administration. Some essential oils are of great interest and continue to be widely studied for their potential ability to retain the qualities of fruits and vegetables and reduce the antitypical symptoms of anthracnose on banana (Chaemsanit et al. 2018; Madjouko et al. 2019). Tangerine oil (TO) can be extracted from citrus fruits and has a distinct flavour and contains various aliphatic aldehydes, esters, and ketones (Miyazaki et al. 2012). Many studies have demonstrated that TO contains a phenolic compound, flavour, and an antimicrobial substance that is helpful in the inhibition of microbial activity, while also enhancing the flavour of food to make it acceptable to the consumer (Matan and Matan 2008; Saengwong-Ngam et al. 2021). Therefore, the objective of this research was to study the effect of $\mathrm{CM}$ and $\mathrm{CM}+\mathrm{TO}$ packaging on the quality of the Kluai Hom Thong banana, by investigating mould growth, bruising, colour, firmness, total soluble solid (TSS), titratable acidity (TA) and $\mathrm{pH}$, during the transportation and storage as well as the potential of the packaging to be reused and its mode of action.

\section{EXPERIMENTAL}

\section{Bananas}

Fresh bananas (Bananas cv. Kluai Hom Thong) were harvested at $70 \%$ to $80 \%$ maturity with no defects, physical damage, or disease and green skin. They came from a commercial farm located in Nakhon Si Thammarat, Thailand. After harvesting, the bananas were immediately brought to the laboratory for cleaning with deionised water for $10 \mathrm{~min}$ and left to air dry. Before the start of the investigation, the bananas were stored in polyethylene bags at a temperature of $30{ }^{\circ} \mathrm{C} \pm 2{ }^{\circ} \mathrm{C}$ and a relative humidity (RH) of $75 \%$ to $80 \%$ (Room temperature and $\mathrm{RH}$ in southern Thailand). 


\section{Tangerine Oil (TO)}

The TO was purchased from the Thai-China Flavour and Fragrance Industry Co., Ltd, Nonthaburi, Thailand. Limonene $(\sim 43 \%)$ in TO was found using gas chromatographymass spectrometry (Thermo Scientific Inc., Austin, TX, USA). Briefly, the Agilent VFWAXms column (dimensions, $30 \mathrm{~m} \times 250 \mu \mathrm{m}$; film thickness, $0.25 \mu \mathrm{m}$ ) was used to separate the volatile compounds of TO. The initial oven temperature was kept at $35{ }^{\circ} \mathrm{C}$ for $4 \mathrm{~min}$; then, the temperature was gradually increased to $200^{\circ} \mathrm{C}$ at a rate of $10{ }^{\circ} \mathrm{C} \mathrm{min}{ }^{-1}$. It was then raised to $250{ }^{\circ} \mathrm{C}$ at a rate of $4{ }^{\circ} \mathrm{C} \min ^{-1}$. It was kept constant for $10 \mathrm{~min}$ at a temperature of $250{ }^{\circ} \mathrm{C}$. The temperature of the injection block and the detector was adjusted to $250{ }^{\circ} \mathrm{C}$. The mass scan was set for acquisition from 35 to $650(\mathrm{~m} / \mathrm{z})$. The volatile compounds were identified by comparing their retention times and $\mathrm{m} / \mathrm{z}$, values stored in the Wiley $8 \mathrm{n}$ mass computer library and NIST $0.8 \mathrm{~L}$ (National Inst. of Standards and Technology).

\section{Plant Cushioning Material (CM) Preparation}

The CM (approximately 400 pieces, with a $\phi 1 \mathrm{~cm}$ and a length of $3 \mathrm{~cm}$, density $\sim 0.25 \pm 0.03 \mathrm{~g} / \mathrm{mL}$ ) was prepared from $4 \mathrm{~g}$ of bamboo fibre and $1 \mathrm{~g}$ of water lettuce root for six pieces. The small sized bamboo fibres $(600 \mu \mathrm{m}$ to $850 \mu \mathrm{m})$ were prepared from bamboo lumber. The water lettuce roots (approximately 4 weeks of growth and $20 \mathrm{~cm}$ to $35 \mathrm{~cm}$ long) were collected from a pond. The root was cleaned with water to remove soil or other dirt. Then, the bamboo fibres and water lettuce roots were dried at a temperature of $60{ }^{\circ} \mathrm{C}$ for $3 \mathrm{~h}$, or until the moisture content was approximately 15\%. All plant materials were collected from the Thasala district of the Nakhon Si Thammarat province in Thailand.

For the cushioning processing, the bamboo fibre and the water lettuce root were mixed with $3 \mathrm{~g}$ of rubber latex and $200 \mathrm{~mL}$ of water in a blender (Philips, Thailand) to produce the CM. The solution was boiled at $100^{\circ} \mathrm{C}$ for $5 \mathrm{~min}$. After cooling for $40 \mathrm{~min}$ at room temperature, $\mathrm{TO}$ at $200 \mu \mathrm{L} \cdot \mathrm{g}^{-1}$ was added into the fibre solution and mixed with the blender for $5 \mathrm{~min}$. Then, paste of the $\mathrm{CM}$ or $\mathrm{CM}+\mathrm{TO}$ was poured into the mini long stainless mold with a diameter of $1 \mathrm{~cm}$ and a length of $3 \mathrm{~cm}$. All stainless molds were dried to a temperature of $60{ }^{\circ} \mathrm{C}$ or until the moisture content reached approximately $12 \%$ and was kept at temperature of $25{ }^{\circ} \mathrm{C} \pm 2{ }^{\circ} \mathrm{C}$ at a $\mathrm{RH}$ of $65 \% \pm 5 \%$ before use. All $\mathrm{CM}$ and $\mathrm{CM}+\mathrm{TO}$ were kept at $27 \pm 2{ }^{\circ} \mathrm{C}$ with $65 \pm 5 \%$ relative humidity $(\mathrm{RH})$ in an environmental chamber until the moisture content fell below $12 \%$.

\section{Effects of the Plant Cushioning Material (CM) and Tangerine Oil (TO) on the Bruising and Microbial Growth of Bananas After Transportation and its Reuse Potential}

In this study, a banana box ( $30 \mathrm{~cm}$ wide $\times 40 \mathrm{~cm}$ long $\times 23 \mathrm{~cm}$ high) with $300 \mathrm{~g}$ of $\mathrm{CM}+\mathrm{TO}$ (15 boxes, fives boxes per round experiment, three replicates), CM (15 boxes), and standard size $(10 \mathrm{~mm})$ of air bubble cushioning with double layer $(22 \mathrm{~cm}$ wide $\times 31$ $\mathrm{cm}$ long, commercial control, 15 boxes) were prepared for an approximately $2 \mathrm{~kg}$ of packet of fresh bananas. After packing, each box of bananas was shaken gently $(120 \mathrm{rpm})$ for 12 h using a shaker (Lab Tech, Daihan Labtech Co., Ltd, Kyungki-Do, South Korea) in order to replicate the transportation conditions, and they were then stored at a temperature of 30 ${ }^{\circ} \mathrm{C}$ for $14 \mathrm{~d}$.

For the study regarding the reuse of the packaging (two, three, or four times), after using for the first time, the CM was transferred to a new box (the second usage was $14 \mathrm{~d}$ 
after being used from the $1^{\text {st }}$ round). Then, the material from the second and third rounds was transferred to the third and fourth boxes, respectively (Fig. 1.). After shaking and storing for $14 \mathrm{~d}$, the bruised areas and mould growth were measured.
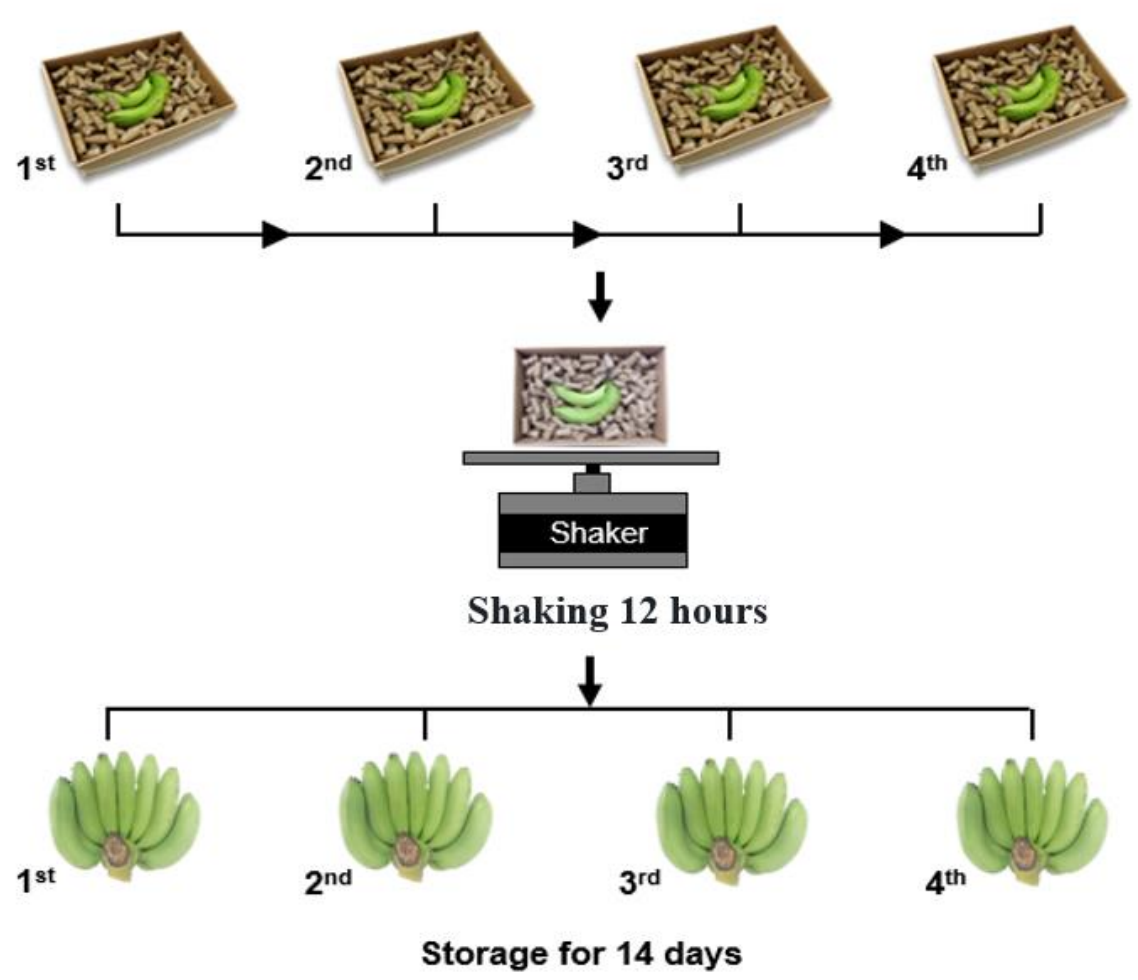

Fig. 1. Fruit box and the reused pattern for the first, second, third and fourth rounds, respectively

Bruising susceptibility was evaluated on whole bananas following a scale of 1 to 4 after $14 \mathrm{~d}$ (Durham et al. 2005). The level system for bruising, markings, and damage was as follows: 1) more than $50 \%$ of the fruit on display had negative quality characteristics; 2) $30 \%$ to $50 \%$ of the fruit on display had negative quality characteristics; 3) $10 \%$ to $30 \%$ of the fruit on display had negative quality characteristics; and 4) less than $10 \%$ of the fruit on display had negative quality characteristics.

After shaking for $12 \mathrm{~h}$, the disease severity on the banana surface was evaluated through fungal decay on a scale of 0 to 5 after $14 \mathrm{~d}$ of storage, as follows: 0 ) no decay; 2) 1 to 5 spots on the fruit surface; 3) $25 \%$ to $50 \%$ of the fruit surface was decayed; 4) $50 \%$ to $75 \%$ of the fruit surface was decayed; and 5) $75 \%$ to $100 \%$ of the fruit surface was decayed (Zhimo et al. 2017).

\section{Effects of the Plant Cushioning Material (CM) on the Quality of the Bananas}

After harvesting, the approximately $2 \mathrm{~kg}$ of bananas were immediately brought to the laboratory. Two treatments, i.e., $300 \mathrm{~g}$ of CM and $300 \mathrm{~g}$ of CM+TO, were prepared and packed in boxes with the bananas. After packing, each box of bananas was shaken gently for $12 \mathrm{~h}$ using a shaker (Lab Tech, Daihan Labtech Co., Ltd) to simulate the transportation conditions and then stored at a temperature of $30{ }^{\circ} \mathrm{C}$ for $14 \mathrm{~d}$. The treated fruit $(\mathrm{CM}+\mathrm{TO})$ and control (CM) were evaluated for quality evaluation in terms of physiological loss and chemical change after $14 \mathrm{~d}$ of storage. Three replicates with five boxes for each treatment were observed after $1,3,5,7$, and 14 days of treatment. 


\section{Determination of the firmness}

The firmness of the bananas was measured using a texture analyzer (LR 5K, LLOYD Instruments, West Sussex, UK) with a spherical stainless probe with a $2 \mathrm{~mm}$ diameter and a compression load of $2 \mathrm{~mm} \cdot \mathrm{min}^{-1}$. The firmness was measured to a depth of $1.5 \mathrm{~cm}$ from the centre of the banana with eight replicates for each sample, and the results were expressed as Newton $(\mathrm{N})$ load cells. Bananas with skin that were $10 \mathrm{~cm}$ in length were cut from the end, middle, and tip regions. The mean values of the puncture forces were considered. Each cylindrical sample was used once per measurement. In addition, data analysis was performed using Nexygen software (version 3.0 plus, LLOYD Instruments, West Sussex, UK). The first highest peak was considered as the maximum force or firmness $(\mathrm{N})$.

\section{Determination of the total soluble solids (TSS), pH, and titratable acidity (TA)}

Banana pulp and 5 to $10 \mathrm{~g}$ of sterile water was homogenized in a kitchen blender for $1 \mathrm{~min}$, and the mixture was extracted via filtration as banana juice. This was evaluated for TSS expressed as ${ }^{\circ}$ Brix using a hand refractometer (Master-T, Atago Co. Ltd., Bellevue, WA). Additionally, the banana juice was evaluated for $\mathrm{pH}$ using a $\mathrm{pH}$ meter (model ST3100-F, Ohaus Corp., Parsippany, NJ). The TA was added to the banana juice diluted in water (a 1 to 2 ratio) and titrated with $0.1 \mathrm{~N}$ of $\mathrm{NaOH}$ (a pH of 8.2) using phenolphthalein as an indicator. The results were expressed as a percentage of malic acid per 100 fresh weight. The TSS, pH, and TA analyses were done in triplicate.

\section{Determination of the peel colour}

The colour of the banana peel was measured using a MiniScan EZ (Hunter Associates Laboratory, Reston, VA) and based on the CIELAB colour parameters to obtain $L^{*}$ (light or dark), $a^{*}$ (red or green) and $b^{*}$ (yellow or blue) values. The colourimeter was calibrated using a white standard tile before its use. Five fruits per replication from each treatment were evaluated and the measurements were performed in triplicate. The total colour difference $(\Delta E)$ was calculated according to Eq. 1,

$$
\Delta E=\sqrt{(\Delta L *)^{2}+(\Delta a *)^{2}+\left(\Delta b *^{2}\right)}
$$

where $\Delta L^{*}, \Delta a^{*}$, and $\Delta b^{*}$ represents the difference in the $L^{*}, a^{*}, b^{*}$ values at a particular interval from the respective initial values.

\section{Microstructure morphology of the banana peel}

The morphological properties of the banana peel kept inside a paper box with the commercial (air bubble), CM, and CM+TO after transportation and storage for $7 \mathrm{~d}$ were observed via scanning electron microscopy (SEM) (Merlin compact, Carl Zeiss, Jena, Germany). The banana peel samples were coated with a thin layer of gold before being observed under SEM at $10.0 \mathrm{KV}$ with a 10 to $100 \mu \mathrm{m}$ aperture size.

\section{Statistical Analysis}

All results were expressed as the mean \pm the standard deviation. The data was statistically treated via analysis of variance (ANOVA) and Duncan's post hoc test, with a $p$-value less than 0.05 being considered as statistically significant. The statistical analysis was performed using Statistica software (version 10.0, StatSoft India Pvt. Ltd, Delhi, India). 


\section{RESULTS AND DISCUSSION}

\section{Bruised Area (\%) of the Bananas after Transportation and Storage}

Bruise damage that appeared on the surface of the banana after transportation and storage is illustrated in Fig. 2. When the bananas were stored for $14 \mathrm{~d}$, the bruised area was visible and easy to evaluate on the banana peel. These results indicated that bananas with $\mathrm{CM}+\mathrm{TO}$ and $\mathrm{CM}$ had a smaller bruised area (less than $20 \%$ after $14 \mathrm{~d}$ ) compared to the commercial control (greater than $40 \%$ after $14 \mathrm{~d}$ ). A larger bruised area was found in the control treatment after the fourth transportation cycle. Therefore, reusing the $\mathrm{CM}$ and $\mathrm{CM}+\mathrm{TO}$ packaging four times still protected the banana peel from bruising.

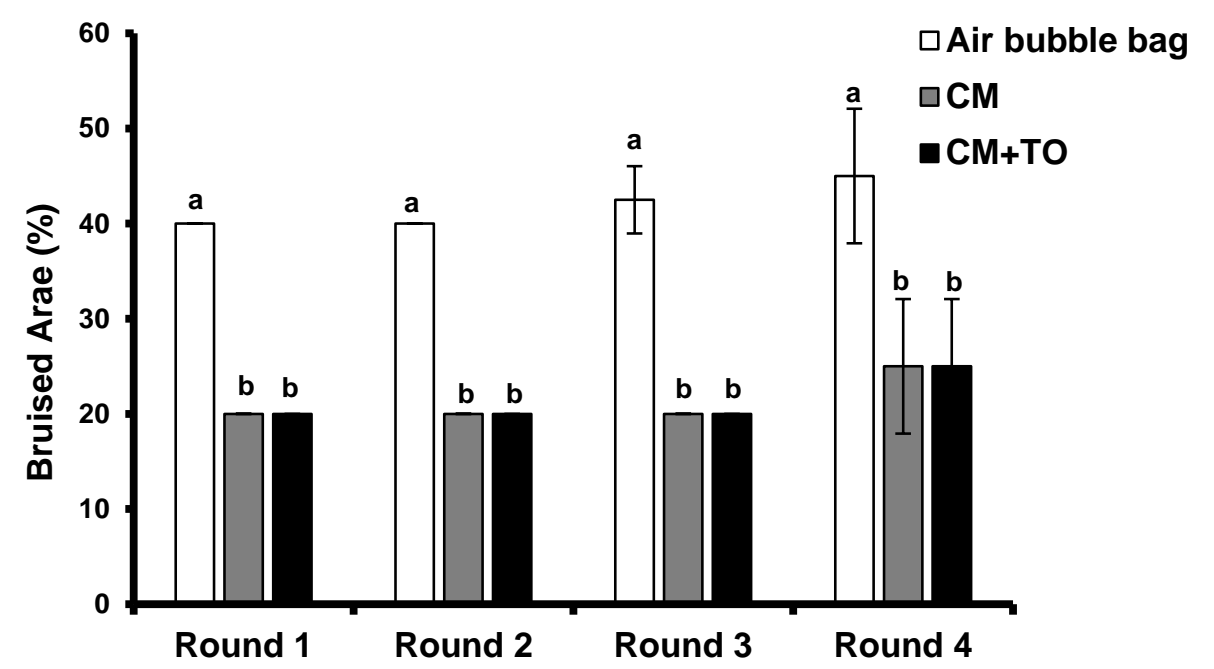

Fig. 2. Effect of the air bubble bag (commercial control), cushioning material (CM), and cushioning material with tangerine oil $(\mathrm{CM}+\mathrm{TO})$ on the total bruised area of a banana after transportation and storage for $14 \mathrm{~d}$ after 1 through 4 rounds of transportation (Note: Error bars indicate standard deviation $( \pm S D)$; and ${ }^{\text {a-b }}$ different superscripts are significantly different ( $p$-value less than 0.05))

Banana bruising contributes to fruit downgrading and rejection, thereby contributing to post-harvest losses. Bruise damage on fresh fruit, e.g., bananas, is physical evidence of bruising that is a result of a cell damage and may also accelerate other biological processes, e.g., microbial spoilage (Prusky 2011; Eissa et al. 2013). Therefore, this increases the risk of microbial contamination, which is a potential cause for fruit quality losses and lower shelf life. As such, the $\mathrm{CM}$ and $\mathrm{CM}+\mathrm{TO}$ packaging were more preventative of bruised or physically damaged fruits compared to the control.

\section{Inhibition of Mould Growth on Bananas After Transportation and Storage}

The effects the CM, CM+TO, and the commercial control on mould growth are illustrated in Fig. 3. The CM+TO packaging reduced mould growth on the surface of the banana by approximately $80 \%$ to $100 \%$ after $14 \mathrm{~d}$ of storage. The TO vapour in the CM+TO packaging clearly inhibited growth of fungal decay infection on the bananas (the growth was less than 20\%), followed by CM (the growth was greater than $40 \%$ ). The decreased inhibited mould growth was found to be significant (a $p$-value less than 0.05) when TO $\left(200 \mu \mathrm{g} \cdot \mathrm{g}^{-1}\right)$ was added to the CM. This was a result of positive mould inhibition, enabling the reuse of $\mathrm{CM}+\mathrm{TO}$ packaging for transportation up to four times. In comparison with the 
commercial control treatment (the growth was greater than 60\%), the mould was found on the surface after storage for 3 to $5 \mathrm{~d}$, and thereafter more quickly grew until $14 \mathrm{~d}$ of storage at a temperature of $30{ }^{\circ} \mathrm{C}$. The TO was extracted from the citrus family of fruits. Its primary component was limonene, which affected the activity of microbial and enzymatic reactions (Ho and Kuo 2014). In addition, TO can be used to extend the shelf life of foods, e.g., bream (Megalobrama amblycephala), apples and blueberries (He and Xiao 2016; Mbili et al. 2017; Umagiliyage et al. 2017). The results from this experiment confirmed that TO can be released from the CM and inhibit natural mould growth on bananas.

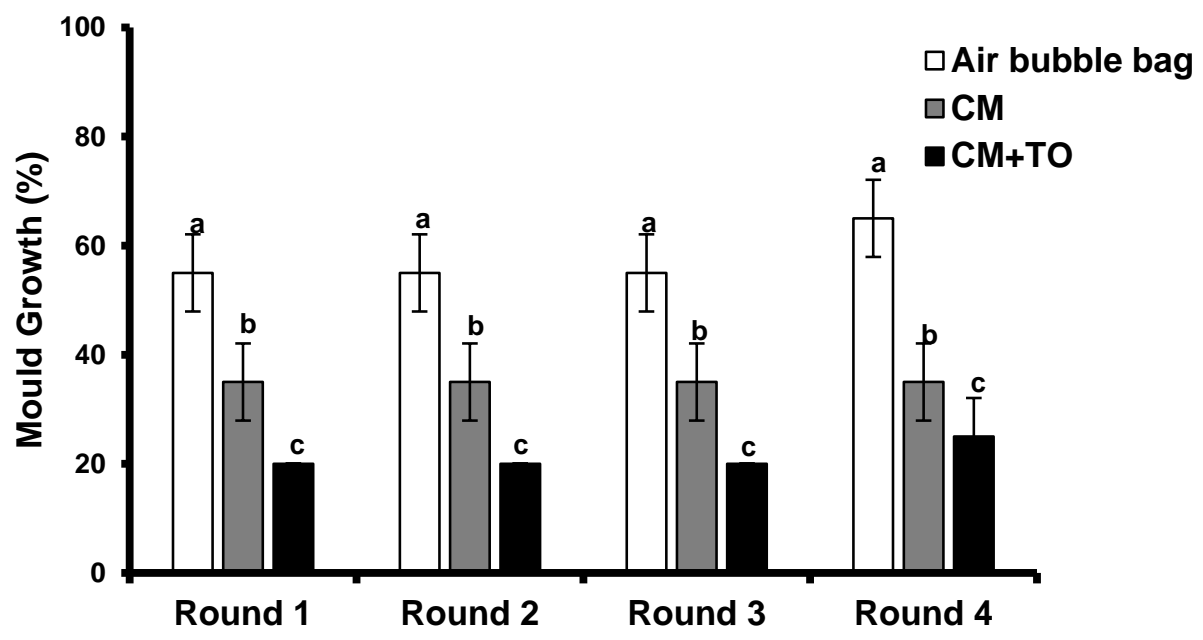

Fig. 3. Effect of the air bubble bag (commercial control), cushioning material (CM), and cushioning material with tangerine oil $(\mathrm{CM}+\mathrm{TO})$ on the total mould growth on the surface of a banana after transportation and storage for $14 \mathrm{~d}$ after 1 through 4 rounds of transportation (Note: Error bars indicate standard deviation $( \pm S D)$; and ${ }^{a-b}$ different superscripts are significantly different ( $p$-value less than 0.05))

Reusable CM for bananas may be seen as a product-service system, in which, instead of simply selling a banana product, a service is provided to the consumer. There is a choice of packaging depending on the opportunities and impacts of fruit service systems. Currently, the results from the experiment indicate that the CM can be reused at least four times with good quality bananas, and this indicates a positive side in terms of its environmental and economic impacts. The results will help to not only provide the possibility of CM and CM+TO packaging, but also help identify the potential of reducing the environmental impacts, as well as the plant barriers to the implementation of integrated reusable packaging systems.

\section{Effects of the Plant Cushioning Material (CM) with Tangerine Oil (TO) on Apparency Quality of Banana}

Firmness, TSS, $p H$, and TA

The banana firmness in all boxes is illustrated in Fig. 4a. The results clearly showed that the firmness of the bananas in the $\mathrm{CM}+\mathrm{TO}$ packaging was different from the firmness of the bananas in the CM after $5 \mathrm{~d}$ of storage. The firmness of the treated banana $(\mathrm{CM}+\mathrm{TO})$ was found to be lower than the firmness of the banana in CM. This result was related to the colour of the treated banana, which had a higher yellow value than the CM bananas (Table 1). 
(a)
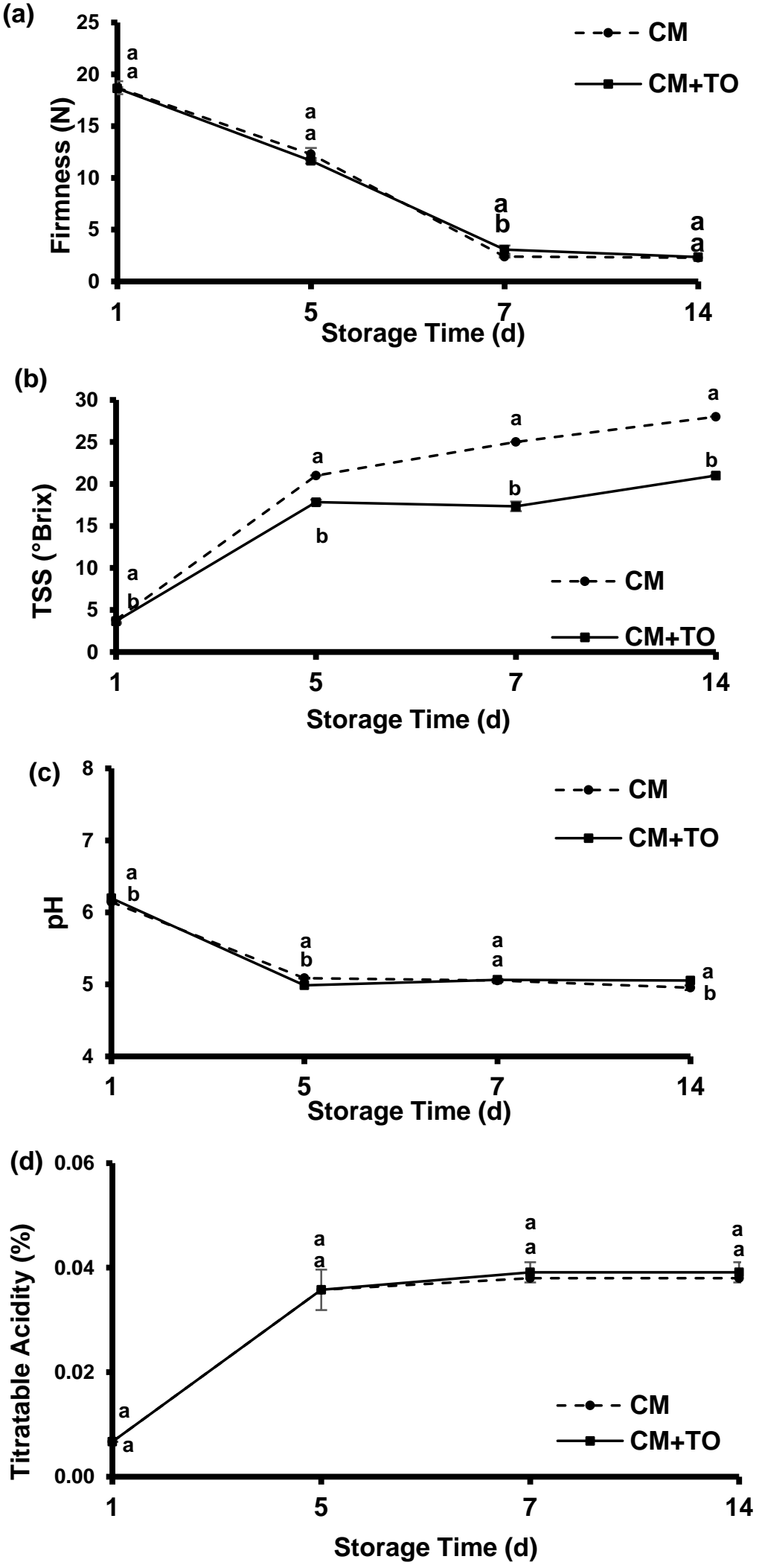

Fig. 4. Effect of cushioning material $(\mathrm{CM})$ and $\mathrm{CM}$ with tangerine oil $(\mathrm{CM}+\mathrm{TO})$ on the firmness (a); total soluble solids (b); $\mathrm{pH}$ (c); and titratable acidity (d) of a banana after transportation and storage for $14 \mathrm{~d}$ after 1 through 4 rounds of transportation (Note: Error bars indicate standard deviation ( \pm SD); and ${ }^{\text {a-b }}$ different superscripts are significantly different ( $p$-value less than 0.05$)$ ) 
However, the firmness of the banana after $7 \mathrm{~d}$ of storage was similar between the bananas in the $\mathrm{CM}+\mathrm{TO}$ and $\mathrm{CM}$ packaging. The firmness is an indicator of banana ripeness, which is indicated by a decreasing firmness (Al-Qurashi et al. 2017). The cell wall contained pectinesterase and polygalacturonase; these enzymes hydrolyzed the pectin, leading to the destruction and deterioration of the cell wall structure, thus softening the fruit (Bugaud et al. 2007). Biochemical, physiological, and compositional changes associated with ripening, which result in the softening of the bananas, have been reported (Srivastava and Dwivedi 2000; Bugaud et al. 2007).

Table 1. The $L^{*} a^{*} b^{*}$ Values of the Banana Peels in Cushioning Material and Cushioning Material with Tangerine Oil After Transportation and $14 \mathrm{~d}$ of Storage

\begin{tabular}{|c|c|c|c|c|c|}
\hline \multirow{2}{*}{ Colour } & \multirow{2}{*}{ Treatment } & \multicolumn{4}{|c|}{ Storage Time $(\mathrm{d})$} \\
\cline { 3 - 6 } & & 1 & 5 & 7 & 14 \\
\hline \multirow{2}{*}{$L^{*}$} & $\mathrm{CM}$ & $50.17 \pm 1.07^{\mathrm{a}}$ & $65.79 \pm 1.19^{\mathrm{a}}$ & $76.27 \pm 1.78^{\mathrm{a}}$ & $74.23 \pm 2.39^{\mathrm{a}}$ \\
\cline { 2 - 6 } & $\mathrm{CM}+\mathrm{TO}$ & $47.41 \pm 1.12^{\mathrm{b}}$ & $61.25 \pm 0.97^{\mathrm{b}}$ & $75.39 \pm 0.78^{\mathrm{a}}$ & $74.83 \pm 0.94^{\mathrm{a}}$ \\
\hline \multirow{2}{*}{$\mathrm{a}^{*}$} & $\mathrm{CM}$ & $-11.31 \pm 0.36^{\mathrm{b}}$ & $-2.45 \pm 0.94^{\mathrm{a}}$ & $7.25 \pm 1.14^{\mathrm{b}}$ & $9.80 \pm 0.40^{\mathrm{a}}$ \\
\hline \multirow{2}{*}{$b^{*}$} & $\mathrm{CM}+\mathrm{TO}$ & $-10.17 \pm 0.48^{\mathrm{a}}$ & $-0.89 \pm 7.01^{\mathrm{a}}$ & $8.47 \pm 0.89^{\mathrm{a}}$ & $10.08 \pm 0.80^{\mathrm{a}}$ \\
\cline { 2 - 6 } & $\mathrm{CM}$ & $31.92 \pm 1.25^{\mathrm{b}}$ & $41.97 \pm 1.28^{\mathrm{a}}$ & $39.92 \pm 1.91^{\mathrm{b}}$ & $39.47 \pm 2.55^{\mathrm{b}}$ \\
\cline { 2 - 6 }$\Delta E^{*}$ & $\mathrm{CM}+\mathrm{TO}$ & $33.76 \pm 052^{\mathrm{a}}$ & $42.79 \pm 1.19^{\mathrm{a}}$ & $49.25 \pm 3.03^{\mathrm{a}}$ & $59.64 \pm 1.81^{\mathrm{a}}$ \\
\cline { 2 - 6 } & $\mathrm{CM}$ & $1.98 \pm 1.17^{\mathrm{b}}$ & $11.95 \pm 0.54^{\mathrm{a}}$ & $9.98 \pm 2.03^{\mathrm{a}}$ & $10.73 \pm 3.82^{\mathrm{a}}$ \\
\cline { 2 - 6 } & $\mathrm{CM}+\mathrm{TO}$ & $4.92 \pm 0.67^{\mathrm{a}}$ & $12.58 \pm 3.24^{\mathrm{a}}$ & $9.84 \pm 2.27^{\mathrm{a}}$ & $11.24 \pm 1.95^{\mathrm{a}}$ \\
\hline
\end{tabular}

Note: Data are means ( \pm SD); and ${ }^{\text {a-b }}$ different superscripts in a column are significantly different ( $p$-value less than 0.05)

The TSS continued to increase after $5 \mathrm{~d}$ of storage until $14 \mathrm{~d}$, as illustrated in Fig. 4b. Overall, the bananas in CM+TO packaging had a lower TSS (less than $25^{\circ}$ Brix) compared to the bananas in CM packaging. The TSS value is a good indicator of fruit ripening, since starch is hydrolyzed into soluble sugars during ripening (Prabha and Bhagyalakshmi 1998). Additionally, Deng et al. (2017) reported controlling the postharvest physiology of banana surfaces using cellulose nanomaterial $(\mathrm{CN})$-incorporated emulsion coatings; this resulted in an approximate TSS value of $20{ }^{\circ}$ Brix with treatment after 7 and $10 \mathrm{~d}$. This work indicated that the TO vapour from the CM+TO packaging caused low TSS values in the banana fruit and delayed ripening during storage.

The $\mathrm{pH}$ value of the bananas decreased after $3 \mathrm{~d}$ of storage. The results are illustrated in Fig. 4c. The $\mathrm{pH}$ of the bananas decreased with the passage of time, and the values were reduced more in bananas in the CM+TO packaging compared to the $\mathrm{CM}$ packaging. These results agreed with those of multiple studies that reported that the $\mathrm{pH}$ of bananas should decrease to approximately 4.7 to 5.2 after $6 \mathrm{~d}$ to $13 \mathrm{~d}$ (Al-Qurashi et al. 2017). For the TA analysis in this study, the TA of bananas in the CM+TO packaging was not significantly different (a $p$-value less than 0.05) from the bananas in the CM packaging (as shown in Fig. 4d). After 5 d, the TA values of the banana slightly increased. However, the amount of TA was found to be very low overall, only approximately $0.02 \%$ to $0.04 \%$ malic acid. Therefore, the organic acids, e.g., malic acid, in treated-TO and untreated bananas could not induce or relate to enzymatic respiration of fruit during $14 \mathrm{~d}$ of storage.

\section{Colour of the bananas}

Colour is one of the important factors used to analyze the quality of bananas. The $L^{*}, a^{*}$, and $b^{*}$ as well as the $\Delta E$ of the banana peel are presented in Table 1 . The banana 
peel changes colour from green to yellow at higher $L^{*}$ and $b^{*}$ values. Overall, the CM+TO packaging was shown to protect the banana shelf life after transportation, as they had a brighter yellow value when stored for $5 \mathrm{~d}$, followed by the CM packaging. This research used the $L^{*}, a^{*}$, and $b^{*}$ colour values to determine ripening through the change in colour of the bananas after $7 \mathrm{~d}$ to $14 \mathrm{~d}$ of storage. Through the stages of ripening, the colour remained yellow, with the colour changes being dominated by an increasing brightness. In contrast, the banana colour has been reported as non-homogeneous, and measurement via a colourimeter does not cover the whole surface (Mendoza and Aguilera 2004).

\section{Possible Mode of Action}

The microstructure SEM photographs of the banana peel are shown in Fig. 5a through 5c. Intelligent plant-CM and $\mathrm{CM}+\mathrm{TO}$ packaging can considerably affect the microstructure of the banana peel compared to commercial air bubble bags (control). The microstructure change was closely related to the moisture migration from the banana flesh to the peel and the peel to the flesh during ripening. The peel of the bananas in the CM+TO packaging had large sized pores (Fig. 5c), whereas the bananas kept in the CM (Fig. 5b) and air bag (Fig. 5a) packaging had smaller sized pores in the peel. From Fig. 5c, the vapor of TO in CM had been exposed, so as to produce large sizes of pores in the banana peel. The pores allowed moisture to move from the fruit to the air. Normally, during ripening, the moisture content of banana will be decreased, follow by an increase in the TSS, which was observed with a decrease in firmness. Bananas mature by changing from green to yellow. The ripening process is caused by carbohydrate breakdown; the water molecules in the fruit lead to the enhancement of moisture mobility and evaporation, causing osmotic transfer and the increase of pore-size micro-tunnels, which is positive for moisture migration (Maduwanthi and Marapana 2021). The ripening stage of 'Kluai Hom Thong' bananas in this test was found to be similar to the Monthan Banana (Patil and Shanmugasundaram 2015). Therefore, the bananas kept in CM+TO packaging with large sized pores were conducive to water diffusion and migration due to rapid ripening in $7 \mathrm{~d}$, followed by the bananas in CM packaging, with middle sized pores.

In addition, bruising from mechanical damage due to a loss of cell membranes of the fruit produces polyphenol oxidase or peroxidase, which are browning enzymes. These enzymes polymerize to a brown pigment involved in bruise susceptibility (Bugaud et al. 2014). In this experiment, d-limonene was found in banana peel with CM+TO. Nevertheless, limonene affected the reduction in polyphenol enzyme, which caused a remarkable anti-bruising effect and inhibited the growth of mould (Marei et al. 2012).

The strong antifungal activities of limonene have the potential to be used as fungicides in food. Limonene as a natural food preservative is a monoterpene and is derived from citrus fruit. In addition, it is safe to use as a food preservative in the food industry due to its broad spectrum of antimicrobial activity (Liu et al. 2013). In this study, limonene was found to be the primary key in reducing mould growth on the surface of the bananas. Limonene can damage cell membranes and destroy the cellular proteins of microorganisms (Cai et al. 2019). In addition, carveol is one of the components that could extend the shelflife of citrus fruits after harvest, due to its ability to inhibit the germination of spores and increased the permeability of cell membranes, causing a leakage of the cytoplasmic content of fungal mycelia (Yang et al. 2021). This finding in this experiment showed considerable delay of the bruised area of the bananas and inhibited mould spoilage of the bananas after being kept in $\mathrm{CM}+\mathrm{TO}$ packaging because it helped remove moisture and contained limonene and carveol, which attacked the mould. 

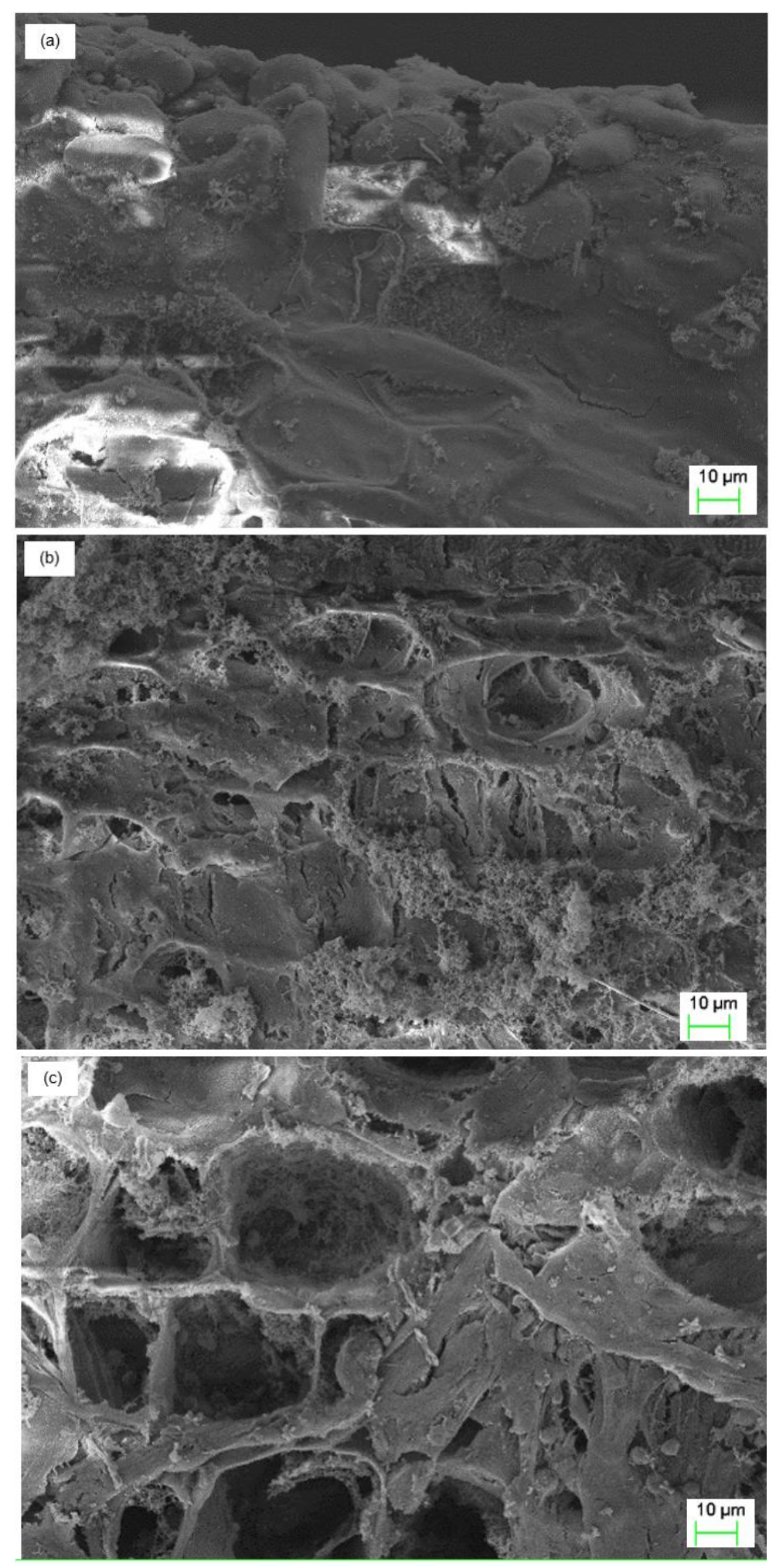

Fig. 5. SEM photographs of the microstructure of banana peels kept inside a paper box with the air bubble bag (commercial control), (a) cushioning material (b), and cushioning material with tangerine oil (c) after transportation and storage for $7 \mathrm{~d}$ 


\section{CONCLUSIONS}

1. The effectiveness of the $\mathrm{CM}+\mathrm{TO}$ treatment $\left(200 \mu \mathrm{g} \cdot \mathrm{g}^{-1}\right)$ for preserving the quality of 'Kluai Hom Thong' bananas during transportation and storage for $14 \mathrm{~d}$ indicated a highly positive technique compared to the conventional packaging.

2. Bananas kept in the $\mathrm{CM}+\mathrm{TO}$ treatment had a satisfactory antifungal effect and a reduction in the total bruised area, but there was some rapid ripening in the first $5 \mathrm{~d}$.

3. The application of $\mathrm{CM}$ or $\mathrm{CM}+\mathrm{TO}$ during the transportation and storage of bananas has been confirmed, and $\mathrm{CM}+\mathrm{TO}$ can be used up to four times, as the advantages of TO being released from the $\mathrm{CM}$ continued to extend the storage life of the bananas.

4. In addition, the high level of efficiency of the $\mathrm{CM}+\mathrm{TO}$ packaging in delivering the absorbed moisture into the $\mathrm{CM}$ was supplemented by decreased microbial activity via the remaining limonene for a period of time.

5. The TO vapour in the $\mathrm{CM}+\mathrm{TO}$ packaging was found to have significance in prevention of mould growth on banana (the growth was less than 20\%), compared to the CM (the growth was greater than $40 \%$ ) for $14 \mathrm{~d}$.

\section{ACKNOWLEDGMENTS}

This study was supported by the Thailand Research Fund (TRF) through the Royal Golden Jubilee Ph.D. Program (Grant. No. PHD/0006/2015) and the Walailak University, Thailand through contact No. WU-COE-64-07.

\section{REFERENCES CITED}

Al-Qurashi, A. D., Awad, M. A., Mohamed, S. A., and Elsayed, M. I. (2017).

"Postharvest chitosan, trans-resveratrol and glycine betaine dipping affect quality, antioxidant compounds, free radical scavenging capacity and enzymes activities of 'Sukkari' bananas during shelf life," Scientia Horticulturae 219, 173-181. DOI: 10.1016/j.scienta.2017.02.046

Bugaud, C., Daribo, M. O., and Dubois, C. (2007). "Climatic conditions affect the texture and colour of Cavendish bananas (Grande Naine cultivar)," Scientia Horticulturae 113(3), 238-243. DOI: 10.1016/j.scienta.2007.03.013

Bugaud, C., Ocrisse, G., Salmon, F., and Rinaldo, D. (2014). "Bruise susceptibility of banana peel in relation to genotype and post-climacteric storage conditions," Postharvest Biology and Technology 87, 113-119. DOI:

10.1016/j.postharvbio.2013.08.009

Cai, R., Hu, M., Zhang, Y., Niu, C., Yue, T., Yuan, Y., and Wang, Z. (2019). “Antifungal activity and mechanism of citral, limonene and eugenol against Zygosaccharomyces rouxii," LWT 106, 50-56. DOI: 10.1016/j.1wt.2019.02.059

Chaemsanit, S., Matan, N., and Matan, N. (2018). "Effect of peppermint oil on the shelflife of dragon fruit during storage," Food Control 90, 172-179. DOI:

10.1016/j.foodcont.2018.03.001

Deng, Z., Jung, J., Simonsen, J., and Zhao, Y. (2017). “Cellulose nanomaterials emulsion 
coatings for controlling physiological activity, modifying surface morphology, and enhancing storability of postharvest bananas (Musa acuminate)," Food Chemistry 232, 359-368. DOI: 10.1016/j.foodchem.2017.04.028

Durham, C. A., McFetridge, M. V., and Johnson, A. J. (2005). "The development of a quality scale to measure the impact of quality on supermarket fruit demand," Journal of Food Distribution Research 36(1), 36-41. DOI: 10.22004/ag.econ.26736

Eissa, A. H. A., Albaloushi, N. S., and Azam, M. M. (2013). "Vibration analysis influence during crisis transport of the quality of fresh fruit on food security," Agricultural Engineering International 15(3), 181-190.

Hao, H., Tam, L., Lu, Y., and Lau, D. (2018). "An atomistic study on the mechanical behavior of bamboo cell wall constituents," Composites Part B: Engineering 151, 222-231. DOI: 10.1016/j.compositesb.2018.05.046

He, Q., and Xiao, K. (2016). "The effects of tangerine peel (Citri reticulatae pericarpium) essential oils as glazing layer on freshness preservation of bream (Megalobrama amblycephala) during superchilling storage," Food Control 69, 339345. DOI: 10.1016/j.foodcont.2016.05.019

Ho, S.-C., and Kuo, C.-T. (2014). "Hesperidin, nobiletin, and tangeretin are collectively responsible for the anti-neuroinflammatory capacity of tangerine peel (Citri reticulatae pericarpium)," Food and Chemistry Toxicology 71, 176-182. DOI: 10.1016/j.fct.2014.06.014

Jagannath, J. H., Gupta, D. K. D., Bawa, A. S., Sebastin, R., and Vishnu, B. (2005). "Assessment of ripeness/damage in banana (Musa paradisiacal) by acoustic resonance spectroscopy," Journal of Food Quality 28(3), 267-278. DOI: 10.1111/j.1745-4557.2005.00008.x

Kamel, M. A. M., Cortesi, P., and Saracchi, M. (2016). "Etiological agents of crown rot of organic bananas in Dominican Republic," Postharvest Biology and Technology 120, 112-120. DOI: 10.1016/j.postharvbio.2016.06.002

Kuyu, C. G., and Tola, Y. B. (2018). "Assessment of banana fruit handling practices and associated fungal pathogens in Jimma town market, southwest Ethiopia," Food Science \& Nutrition 6(3), 609-616. DOI: 10.1002/fsn3.591

Liu, J., Zhu, Y., Du, G., Zhou, J., and Chen, J. (2013). "Exogenous ergosterol protects Saccharomyces cerevisiae from D-limonene stress," Letters in Applied Microbiology 114(2), 482-491. DOI: 10.1111/jam.12046

Madjouko, M. A., Tchameni, S. N., Tchinda, E. S., Jazet, P. M. D., Kamsu, P. N., Kamga, V. A. M. S., Sameza, M. L., Tchoumbougnang, F., and Menut, C. (2019). "Inhibitory effects of essential oils from Ocimum basilicum and Ocimum gratissimum on Colletotrichum musae: The causal agent of bananas anthracnose," Journal of Phytopathology 167(5), 257-264. DOI: 10.1111/jph.12793

Maduwanthi, S. D. T., and Marapana, R. A. U. J. (2021). "Comparison of pigments and some physicochemical properties of banana as affected by ethephon and acetylene induced ripening," Biocatalysis and Agricultural Biotechnology 33, 1-8. DOI: 10.1016/j.bcab.2021.101997

Maqbool, M., Ali, A., Ramachandran, S., Smith, D. R., and Alderson, P.G. (2010). "Control of postharvest anthracnose of banana using a new edible composite coating," Crop Protection 29(10), 1136-1141. DOI: 10.1016/j.cropro.2010.06.005

Marei, G. I. K., Rasoul, M. A. A., and Abdelgaleil, S. A. M. (2012). "Comparative antifungal activities and biochemical effects of monoterpenes on plant pathogenic fungi," Pesticide Biochemistry and Physiology 103(1), 56-61. DOI: 
10.1016/j.pestbp.2012.03.004

Matan, N., and Matan, N. (2008). "Antifungal activities of anise oil, lime oil, and tangerine oil against molds on rubberwood (Hevea brasiliensis)," International Biodeterioration \& Biodegradation 62(1), 75-78. DOI: 10.1016/j.ibiod.2007.07.014

Mbili, N. C., Opara, U. L., Lennox, C. L., and Vries, F. A. (2017). "Citrus and lemongrass essential oils inhibit Botrytis cinerea on 'Golden Delicious', 'Pink Lady' and 'Granny Smith' apples," Journal of Plant Diseases and Protection 124, 499-511. DOI: $10.1007 / \mathrm{s} 41348-017-0121-9$

Mendoza, F., and Aguilera, J. M. (2004). "Application of image analysis for classification of ripening bananas," Journal of Food Science 69(9), E471-E477. DOI: 10.1111/j.1365-2621.2004.tb09932.x

Miyazaki, T., Plotto, A., Baldwin, E. A., Reyes-De-Corcuera, J. I., and Gmitter Jr., F. G. (2012). "Aroma characterization of tangerine hybrids by gas-chromatographyolfactometry and sensory evaluation," Journal of the Science of Food and Agriculture 92(4), 727-735. DOI: $10.1002 /$ jsfa. 4663

Patil, S. K., and Shanmugasundaram, S. (2015). "Physicochemical changes during ripening of Monthan banana," International Journal of Technology Enhancements and Emerging Engineering Research 3(2), 18-21.

Phothisuwan, S., Preechatiwong, W., and Matan, N. (2020). "Enhancement of antibacterial activity of essential oil vapor released from a paper egg tray in combination with UV-C radiation against pathogenic bacteria on chicken eggs," Journal of Food Processing and Preservation 44(10), 1-26. DOI: $10.1111 /$ jfpp. 14794

Prabha, T. N., and Bhagyalakshmi, N. (1998). "Carbohydrate metabolism in ripening banana fruit," Phytochemistry 48(6), 915-919. DOI: 10.1016/S0031-9422(97)00931$\mathrm{X}$

Prusky, D. (2011). "Reduction of the incidence of postharvest quality losses, and future prospects," Food Security 3(4), 463-474. DOI: 10.1007/s12571-011-0147-y

Raybaudi-Massilia, R. M., Mosqueda-Melgar, J., Soliva-Fortuny, R., and Martín-Belloso, O. (2009). "Control of pathogenic and spoilage microorganisms in fresh-cut fruits and fruit juices by traditional and alternative natural antimicrobials," Comprehensive Reviews in Food Science and Food Safety 8(3), 157-180. DOI: 10.1111/j.15414337.2009.00076.x

Saengwong-Ngam, R., Koomhin, P., Songsamoe, S., Matan, N., and Matan, N. (2021). "Combined effects of tangerine oil vapour mixed with banana flavour to enhance the quality and flavour of 'Hom Thong' bananas and evaluating consumer acceptance and responses using electroencephalography (EEG)," Journal of Food Science and Technology (2021), 1-11. DOI: 10.1007/s13197-021-05100-w

Srivastava, M. K., and Dwivedi, U. N. (2000). "Delayed ripening of banana fruit by salicylic acid," Plant Science 158(1-2), 87-96. DOI: 10.1016/S0168-9452(00)00304-6

Tan, T., Rahbar, N., Allameh, S. M., Kwofie, S., Dissmore, D., Ghavami, K., and Soboyejo, W. O. (2011). "Mechanical properties of functionally graded hierarchical bamboo structures," Acta Biomaterialia 7(10), 3796-3803. DOI:

10.1016/j.actbio.2011.06.008

Triest, D., and Hendrickx, M. (2016). "Postharvest disease of banana caused by Fusarium musae: A public health concern?," PLoS Pathogens 12(11), 1-5. DOI:

10.1371/journal.ppat.1005940

Umagiliyage, A. L., Becerra-Mora, N., Kohli, P., Fisher, D. J., and Choudhary, R. (2017). 
"Antimicrobial efficacy of liposomes containing D-limonene and its effect on the storage life of blueberries," Postharvest Biology and Technology 128, 130-137. DOI: 10.1016/j.postharvbio.2017.02.007

Yang, R., Miao, J., Shen, Y., Cai, N., Wan, C., Zou, L., Chen, C., and Chen, J. (2021). "Antifungal effect of cinnamaldehyde, eugenol and carvacrol nanoemulsion against Penicillium digitatum and application in postharvest preservation of citrus fruit," LWT 141, 1-11. DOI: 10.1016/j.lwt.2021.110924

Zhimo, V. Y., Dilip, D., Sten, J., Ravat, V. K., Bhutia, D. D., Panja, B., and Saha, J. (2017). "Antagonistic yeasts for biocontrol of the banana postharvest anthracnose pathogen Colletotrichum musae," Journal of Phytopathology 165(1), 35-43. DOI: 10.1111/jph.12533

Article submitted: July 30, 2021; Peer review completed: October 23, 2021; Revised version received and accepted: October 29, 2021; Published: November 4, 2021. DOI: 10.15376/biores.17.1.37-51 